\title{
Use of Brazilian Kaolin as a Potential Low-cost Adsorbent for the Removal of Malachite Green from Colored Effluents
}

\author{
Natiela Caponia, Gabriela Carvalho Collazzo ${ }^{a}$, Sérgio Luiz Jahna, Guilherme Luiz Dotto ${ }^{a}$, Marcio \\ Antonio Mazutti ${ }^{a}$, Edson Luiz Foletto ${ }^{a} *$ \\ a Department of Chemical Engineering, Federal University of Santa Maria, 97105-900, \\ Santa Maria, Brazil
}

Received: September 15, 2016; Revised: January 24, 2017; Accepted: April 05, 2017

\begin{abstract}
This study investigated the potential of Brazilian kaolin as a low-cost adsorbent for the removal of Malachite Green (MG) from colored effluents. The morphology, chemical structure and surface properties of the adsorbent were investigated by characterization techniques such as X-ray diffraction, N2 adsorption-desorption isotherms, Fourier transform infrared spectroscopy, X-ray fluorescence spectrometry, scanning electron microscopy, thermogravimetric analysis and particle size distribution. A possible technological application of raw kaolin is the MG removal from aqueous media, which was investigated using batch adsorption experiments. The adsorption kinetics was studied using the pseudo-first order, pseudo-second order and Elovich models. The adsorption isotherms were studied using the Langmuir, Freundlich and Sips models. The Elovich model was the more adequate to represent the adsorption kinetic, while the equilibrium was well represented by the Langmuir model. The maximum adsorption capacity, at $\mathrm{pH}$ of 6.3 and temperature of $25^{\circ} \mathrm{C}$, was $128 \mathrm{mg} \mathrm{g}^{-1}$, and this satisfactory result may be associated with some adsorbent properties. Therefore, the results revealed that raw kaolin can be utilized as a promising low-cost adsorbent to remove MG from colored effluents.
\end{abstract}

Keywords: Kaolin, characterization, low-cost adsorbent, adsorption, Malachite Green

\section{Introduction}

Dyes are used as coloring agents in many industries, and if improperly discarded into the environment, it can cause adverse effects to the human life and aquatic ecosystem ${ }^{1,2}$. Some methods used for dye removal from industrial wastewater are flotation ${ }^{3}$, filtration ${ }^{4}$, adsorption ${ }^{5-8}$ and photocatalysis ${ }^{9,10}$. Among the various available methods, the adsorption process is one of the most effective techniques, which has been successfully employed for dye removal from wastewater ${ }^{11-17}$. Adsorption process offers significant advantages such as lowcost, efficiency and operational ease ${ }^{18}$. Low-cost materials may be used as promising dye adsorbents in order to make the adsorption process less expensive. In this sense, several low-cost materials have been used as adsorbents to treat dye-containing wastewater ${ }^{19-23}$. Among them, clay minerals have been used as a potential adsorbents for this purpose ${ }^{23,24}$.

Kaolin is a clay predominantly composed by kaolinite $\left(\mathrm{Al}_{2} \mathrm{Si}_{2} \mathrm{O}_{5}(\mathrm{OH})_{4}\right)^{25}$, which has been widely used in a variety of technological applications ${ }^{26-40}$. Due to the low-cost and large availability, the use of clays like kaolin becomes the adsorption process an attractive and promising technology. Although there are several works in literature reporting the removal of different classes of dyes onto kaolin ${ }^{41-44}$, no studies were found reporting the application of a natural

* e-mail: efolettto@gmail.com kaolin sample from the Rio Grande do Sul State (Brazil) for the removal of Malachite Green dye.

In this context, the aim of the present work was to investigate the potential application of a Brazilian kaolin sample as an adsorbent for the removal of Malachite Green dye from aqueous solution. Kinetic and equilibrium models were studied in order to elucidate the adsorption process.

\section{Materials and Methods}

\subsection{Materials}

The natural kaolin was obtained from a mining company located in Rio Grande do Sul State, Brazil. The sample was used as received. Malachite Green (MG) (Sigma-Aldrich, CAS number: 569-64-2, $\mathrm{C}_{23} \mathrm{H}_{25} \mathrm{ClN}_{2}, 364.91 \mathrm{~g} \mathrm{~mol}^{-1}$ ) was used as target dye pollutant. The chemical structure of $\mathrm{MG}$ dye is shown in Figure 1.

\subsection{Characterization techniques}

X-ray diffraction pattern (XRD) was obtained using a Rigaku Miniflex 300 diffractometer, where, the X-ray source was $\mathrm{Cu}-\mathrm{K} \alpha$ radiation, powered at $30 \mathrm{kV}$ and $10 \mathrm{~mA}$. Scans were performed over $2 \theta$ angles ranging from 5 to $70^{\circ} . \mathrm{N}_{2}$ adsorption-desorption isotherms were obtained at $77 \mathrm{~K}$ using an ASAP 2020 apparatus. The particle size distribution 


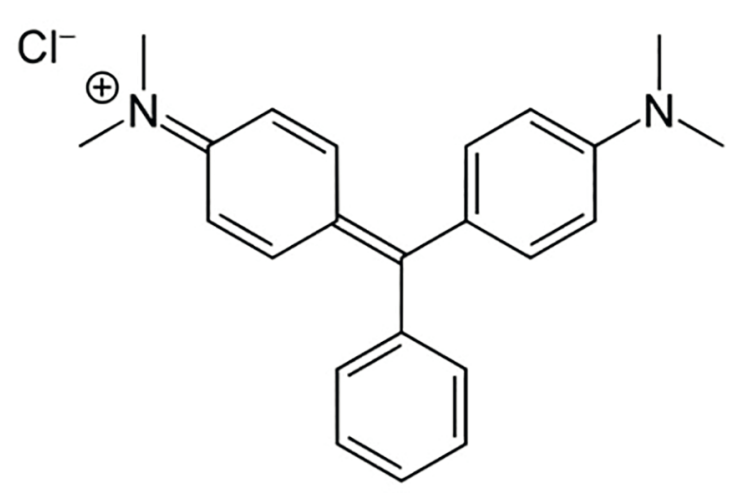

Figure 1. Chemical structure of MG dye.

was measured using a laser particle size analyzer (Malvern Mastersizer 2000). Derivative thermogravimetric analysis (DTA) and thermogravimetric analysis (TGA) were carried out in a Netzsch STA 409 analyzer, at a heating rate of $10^{\circ} \mathrm{C}$ $\mathrm{min}^{-1}$ and air flow rate of $35 \mathrm{~mL} \mathrm{~min}^{-1}$. The sample morphology was examined by a scanning electron microscope (SEM, JEOL JSM-6610LV) at $15 \mathrm{kV}$. Chemical composition of the sample was determined by X-ray fluorescence spectrometry (XRF) (Bruker S8 Tiger equipment). Fourier transform infrared (FTIR) spectrum was recorded on a Shimadzu IRPrestige-21 spectrophotometer in the range of $4000-375 \mathrm{~cm}^{-1}$.

\subsection{Adsorption experiments}

In order to determine the adsorption capacity of the kaolin adsorbent, various concentrations (100 - $\left.175 \mathrm{mg} \mathrm{L}^{-1}\right)$ of the MG dye were prepared and, $100 \mathrm{~mL}$ of each were added to $0.1 \mathrm{~g}$ of adsorbent. All the adsorption experiments were performed at natural $\mathrm{pH}$ of dye solution $(\mathrm{pH}=6.3)$. The mixtures were agitated on a shaker for $240 \mathrm{~min}$ at $100 \mathrm{rpm}$ and $25^{\circ} \mathrm{C}$. After, the solutions were centrifuged (Centribio, 80-2B, Brazil) and immediately analyzed using a UV-vis spectrophotometer (Bel Photonics, SP1105) at $618 \mathrm{~nm}$ to verify the residual MG concentration. All experiments were carried out in triplicates and blanks were performed. The equilibrium adsorption capacity $\left(q_{e}\right)$ and adsorption capacity at any time $\left(q_{t}\right)$ were determined by Equations (1) and (2), respectively:

$$
\begin{aligned}
& q_{e}=\frac{V\left(C_{0}-C_{e}\right)}{m} \\
& q_{t}=\frac{V\left(C_{0}-C_{t}\right)}{m}
\end{aligned}
$$

where, $C_{0}$ is the initial dye concentration in liquid phase ( $\left.\mathrm{mg} \mathrm{L}^{-1}\right), C_{e}$ is the equilibrium dye concentration in liquid phase $\left(\mathrm{mg} \mathrm{L}^{-1}\right), C_{t}$ is the dye concentration in liquid phase at any time $\left(\mathrm{mg} \mathrm{L}^{-1}\right), m$ is the amount of adsorbent $(\mathrm{g})$ and $V$ is the volume of solution (L).

\subsection{Kinetic and equilibrium modeling}

Some kinetic and equilibrium models were employed to interpret the $\mathrm{MG}$ adsorption process on the kaolin adsorbent. Regarding to the kinetic models, pseudo first-order ${ }^{45}$, pseudo second-order ${ }^{46}$ and Elovich models ${ }^{47}$ were used. These models are given by the Equations (3), (4) and (5), respectively:

$$
\begin{array}{r}
q_{t}=q_{1}\left(1-\exp \left(-k_{1} t\right)\right) \\
q_{t}=\frac{t}{\left(1 / k_{2} q_{2}^{2}\right)+\left(t / q_{2}\right)} \\
q_{t}=\frac{1}{b} \ln (1+a b t)
\end{array}
$$

where, $k_{1}$ and $k_{2}$ are the rate constants of pseudo firstorder $\left(\mathrm{min}^{-1}\right)$ and pseudo second-order $\left(\mathrm{g} \mathrm{mg}^{-1} \mathrm{~min}^{-1}\right)$ models, respectively; $q_{1}$ and $q_{2}$ are the theoretical values for the adsorption capacity $\left(\mathrm{mg} \mathrm{g}^{-1}\right), a$ is the initial velocity due to $d q / d t$ with $q_{t}=0\left(\mathrm{mg} \mathrm{g}^{-1} \mathrm{~min}^{-1}\right), b$ is the desorption constant of the Elovich model $\left(\mathrm{g}^{-1} \mathrm{mg}^{-1}\right)$ and $t$ is the time (min).

The equilibrium curves were interpreted by the Freundlich ${ }^{48}$, Langmuir ${ }^{49}$ and Sips ${ }^{50}$ isotherm models. These models are given by the Equations (6), (7) and (8), respectively,

$$
\begin{array}{r}
q_{e}=K_{F} C_{e}^{1 / n_{F}} \\
q_{e}=\frac{q_{m} K_{L} C_{e}}{1+\left(K_{L} C_{e}\right.} \\
q_{e}=\frac{q_{S}\left(K_{S} C_{e}\right)^{m s}}{1+\left(K_{S} C_{e}\right)^{m s}}
\end{array}
$$

where, $K_{F}$ is the Freundlich constant $\left(\mathrm{mg} \mathrm{g}^{-1}\right)\left(\mathrm{mg} \mathrm{L}^{-1}\right)^{-1 / n F}$, $1 / n_{F}$ is the heterogeneity factor, $q_{m}$ is the maximum adsorption capacity $\left(\mathrm{mg} \mathrm{g}^{-1}\right), K_{L}$ is the Langmuir constant $\left(\mathrm{L} \mathrm{mg}^{-1}\right), q_{S}$ is the maximum adsorption capacity from Sips model $\left(\mathrm{mg} \mathrm{g}^{-1}\right)$, $K_{S}$ is the Sips constant $\left(\mathrm{L} \mathrm{mg}^{-1}\right)$ and $m s$ is the Sips exponent.

\subsection{Parameters estimation}

The kinetic and equilibrium parameters were determined by the fit of the models with the experimental data using nonlinear regression. The parameters were estimated by the minimizing the least squares function using the QuasiNewton estimation method. The calculations were carried out using the Statistic 9.1 software (Statsoft, USA) ${ }^{51}$. The fit quality was verified by the obtainment of determination coefficient $\left(R^{2}\right)$, average relative error $(A R E)$ and Akaike information criterion $(A I C)^{52,53}$, which are presented in the Equations (9), (10) and (11), respectively:

$R^{2}=\left(\frac{\sum_{i}^{n}\left(q_{i, \text { exp }}-\bar{q}_{i, \exp }\right)^{2}-\sum_{i}^{n}\left(q_{i, \exp }-q_{i, \text { mode } l}\right)^{2}}{\left.\sum_{i}^{n} q_{i, \text { exp }} \bar{q}_{i, \text { exp }}\right)^{2}}\right)$ 


$$
\begin{gathered}
A R E=\frac{100}{n} \sum_{i=1}^{n}\left|\frac{q_{i, \text { model }}-q_{i, \exp }}{q_{i, \exp }}\right| \\
A I C=n \ln \left(\frac{S S E}{n}\right)+2 p+ \\
\frac{2 p(p+1)}{n-p-1}
\end{gathered}
$$

where, $q_{i \text { model }}$ corresponds to each value of $q$ predicted by the fitted model, $q_{i, e x p}$ corresponds to each value of $q$ experimentally measured, $\bar{q}_{i, \text { exp }}$ is the average of $q$ experimentally measured, $n$ is the number of experimental points, $p$ is the number of parameters of the fitted model and, the sum of squared errors (SSE) is given by the Equation (12):

$$
S S E=\sum_{i=1}^{n}\left(q_{i, \bmod e l}-q_{i, \mathrm{exp}}\right)^{2}
$$

\section{Results and Discussion}

\subsection{Characterization of kaolin}

XRD pattern of raw kaolin is shown in Figure 2. The main reflections of kaolinite were at $2 \theta=12.36^{\circ}, 19.94^{\circ}$, $24.90^{\circ}, 35.98^{\circ}, 38.46^{\circ}, 45.66^{\circ}, 55.12^{\circ}$ and $62.34^{\circ}$, which is matched with the JCPDS database file (PDF-01-089-6538). These findings are consistent with other previously reported works $^{54,55}$. Therefore, the sample showed a predominant phase as kaolinite, and also, quartz as minor impurity. The chemical composition (wt.\%) obtained from XRF analysis of natural kaolin was: $43.50\left(\mathrm{SiO}_{2}\right), 40.03\left(\mathrm{Al}_{2} \mathrm{O}_{3}\right), 0.56$ $\left(\mathrm{Fe}_{2} \mathrm{O}_{3}\right), 0.33\left(\mathrm{~K}_{2} \mathrm{O}\right), 0.27(\mathrm{MgO}), 0.17(\mathrm{CaO}), 0.08\left(\mathrm{TiO}_{2}\right)$, $0.02(\mathrm{MnO}), 0.02\left(\mathrm{SO}_{3}\right), 15.01$ (Mass loss on ignition, obtained from TGA analysis). Typically, a pure kaolinite mineral is made up of $46.5 \mathrm{wt} \%$ of $\mathrm{SiO}_{2}$ and $39.5 \mathrm{wt} \%$ of $\mathrm{Al}_{2} \mathrm{O}_{3}$, and exhibits $14 \mathrm{wt} . \%$ of mass loss on ignition ${ }^{56}$. Therefore, the composition of the kaolin used in this work was close to a kaolinite mineral with high purity degree. The minor differences can are attributed to the presence of accessory minerals.

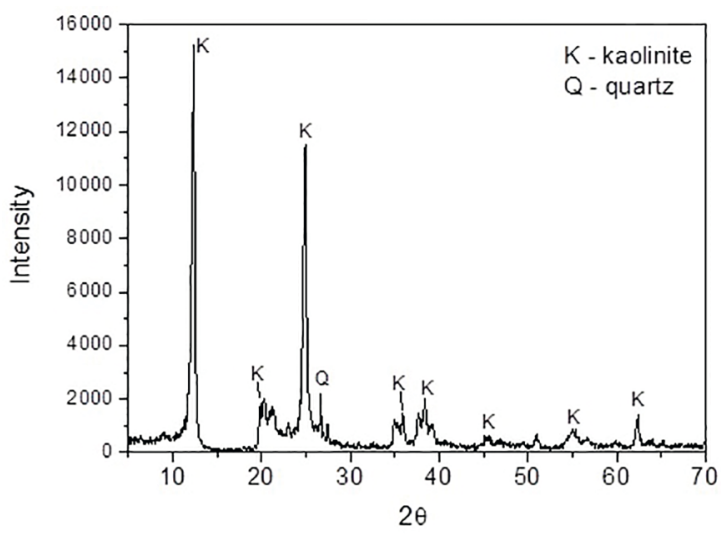

Figure 2. XRD pattern of raw kaolin.
FTIR spectrum of raw kaolin is shown in Figure 3. The main characteristic bands of the kaolinite are highlighted in Figure 3. The bands at 3694 and $3619 \mathrm{~cm}^{-1}$ (OH stretching vibrations), 1114 and $694 \mathrm{~cm}^{-1}$ (Si-O stretching), 1031 $\mathrm{cm}^{-1}$ (Si-O-Si), 1008 and $540 \mathrm{~cm}^{-1}$ (Si-O-Al) and, $912 \mathrm{~cm}^{-1}$ $(\mathrm{Al}-\mathrm{OH})$ are typical of kaolinite mineral ${ }^{56,57}$. Bands located at 789,753 and $468 \mathrm{~cm}^{-1}$ can be attributed to the presence of quartz ${ }^{57-60}$. Vibration at $432 \mathrm{~cm}^{-1}$ can be related to the deformation mode of Si-O or Al-O bonds ${ }^{61}$.

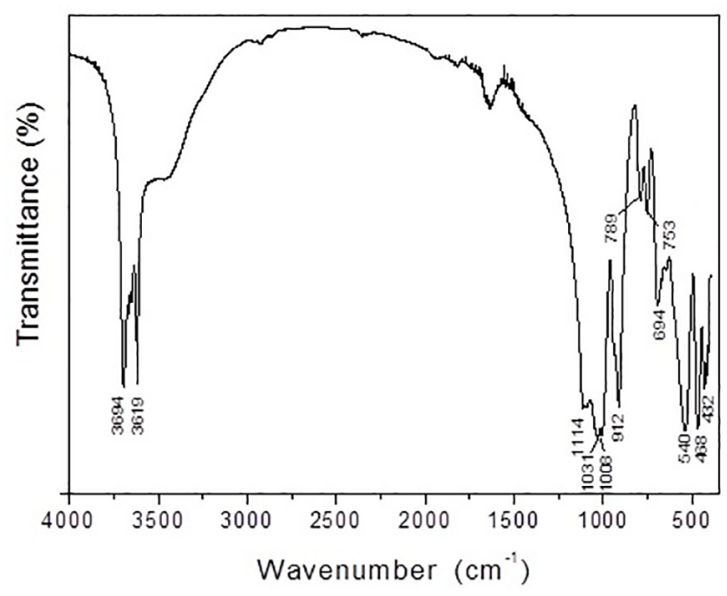

Figure 3. FTIR spectrum of raw kaolin.

Figure 4 shows the DTA/TGA curves for the natural kaolin. From these curves, it can be seen the first endothermic peak around $50{ }^{\circ} \mathrm{C}$, which corresponds to the adsorbed water loss (about 1.3 wt.\%). The second peak centered at 500 ${ }^{\circ} \mathrm{C}$ corresponds to the mass loss (about 13.7 wt.\%) due to kaolinite dehydroxylation toward the formation of a noncrystalline phase (metakaolinite $)^{62,63}$.

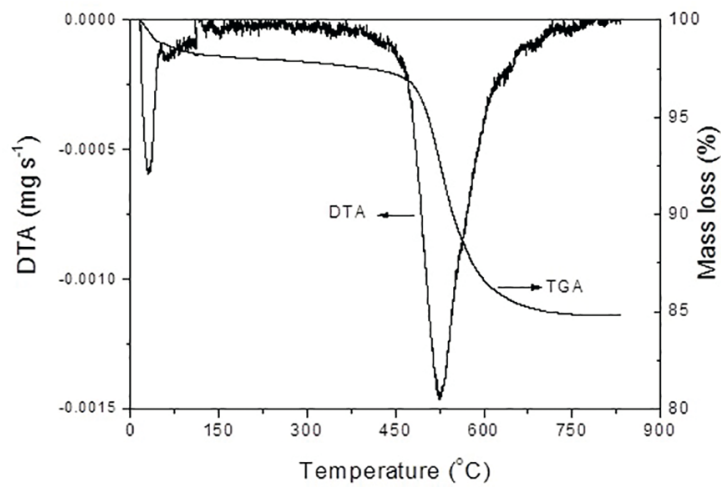

Figure 4. DTA and TGA curves of natural kaolin.

The particle size distribution curve of kaolin is shown in Figure 5. It was found that the kaolin particles are in the range of $0.72-120 \mu \mathrm{m}$, resulting in an average particle size of $23.45 \mu \mathrm{m}(0.2345 \mathrm{~mm})$. This particle size can explain the 
mesoporosity of material due to a variety of pore voids among the particles caused by its agglomeration ${ }^{64}$. Therefore, this mesoporous structure is interesting for adsorption purposes.

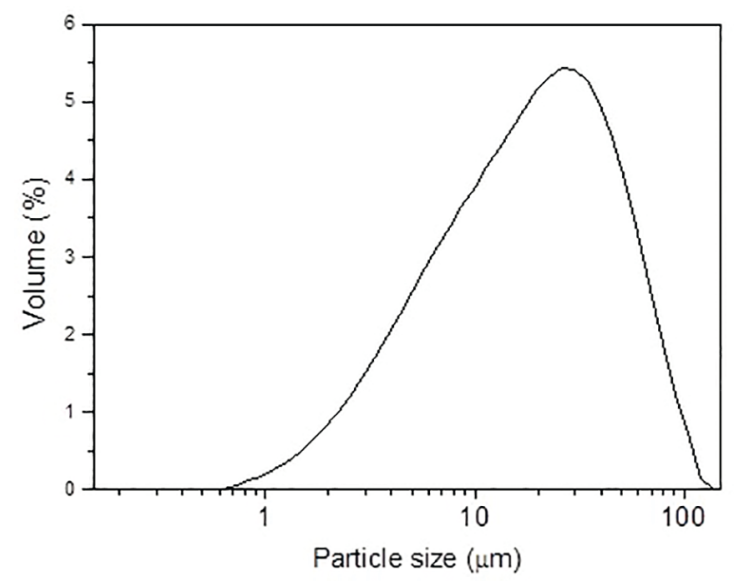

Figure 5. Particle size distribution curve of kaolin.

The morphology of kaolin clay observed in SEM image (Figure 6), indicates that the particles presented irregular shape, rough surface, and different particle sizes (smaller than $50 \mu \mathrm{m})$.

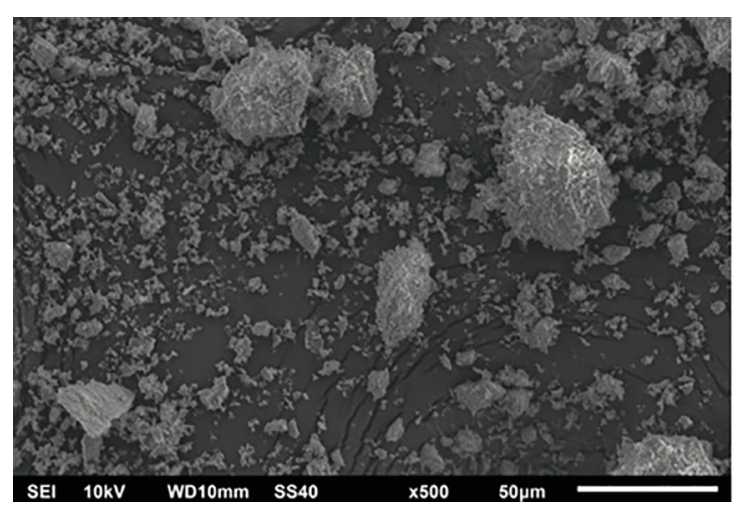

Figure 6. SEM image of raw kaolin.

The $\mathrm{N}_{2}$ adsorption-desorption isotherms and the pore size distribution of kaolin adsorbent are exhibited in Figure 7. This figure indicates the $\mathrm{N}_{2}$ adsorbed/desorbed from the sample in relation to the relative pressure $\left(\mathrm{P} / \mathrm{P}_{0}\right)$ and is used to identify the pore constitution of the material. As shown in Figure 7, the $\mathrm{N}_{2}$ adsorption-desorption isotherms of adsorbent can be classified as type IV, with type-H3 hysteresis behavior, which are indicative of predominantly mesoporous material. In addition, the material exhibited a narrow pore distribution with a maximum peak centered at $4.0 \mathrm{~nm}$, indicating mesoporous characteristics, according to IUPAC. The BET specific surface area, total pore volume and average pore size of the adsorbent were $16.75 \mathrm{~m}^{2} \mathrm{~g}^{-1}$, $0.0628 \mathrm{~cm}^{3} \mathrm{~g}^{-1}$ and $13.5 \mathrm{~nm}$, respectively.

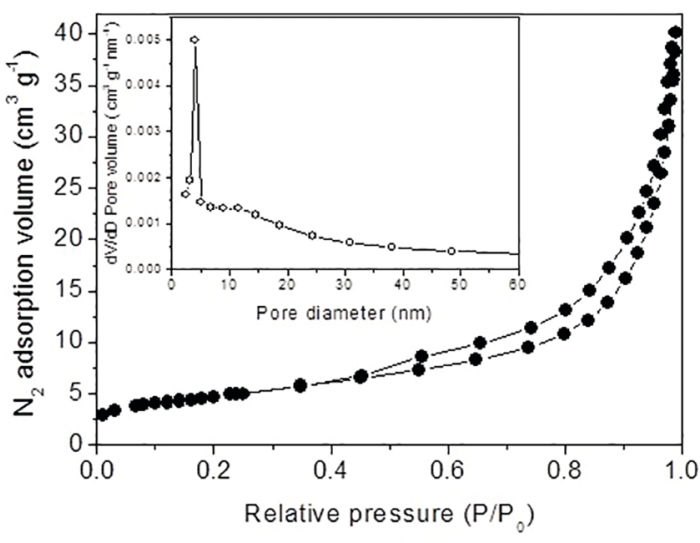

Figure 7. $\mathrm{N}_{2}$ adsorption/desorption isotherms of kaolin and the corresponding pore size distribution (inset).

\subsection{Adsorption kinetic results}

The experimental kinetic curves of MG adsorption on kaolin were constructed at different initial dye concentrations $\left(100,125,150\right.$ and $\left.175 \mathrm{mg} \mathrm{L}^{-1}\right)$ and the respective data were fitted using the pseudo-first order, pseudo-second order and Elovich models. These results are presented in Figure 8 and Table 1.

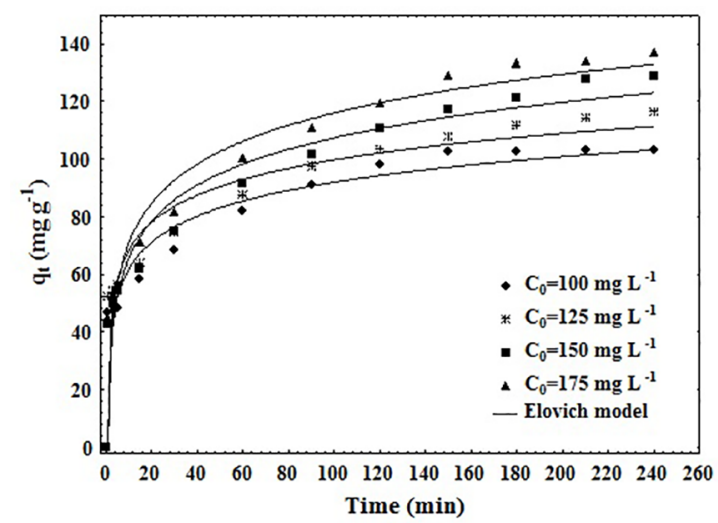

Figure 8. Kinetic curves for the adsorption of MG onto natural kaolin. Experimental conditions: $\mathrm{pH}=6.3 ; \mathrm{T}=25^{\circ} \mathrm{C}$; Adsorbent mass $=0.1 \mathrm{~g} ; \mathrm{V}_{\text {solution }}=100 \mathrm{~mL}$.

It can be noticed in Figure 8 that the curves were overlapped until the first $20 \mathrm{~min}$. Until $60 \mathrm{~min}$, more than $70 \%$ of saturation was attained independent of the initial dye concentration. The equilibrium was reached around 240 min. Based on the statistical parameters $\left(R^{2}>0.96\right),\left(R_{a d j}^{2}>\right.$ $0.96),(A R E<8.0 \%),(S S E<630)$ and $(A I C<56)$ (Table 1$)$, it can be clearly observed that the Elovich model was the most suitable to represent the MG adsorption onto kaolin. At higher initial dye concentrations, the parameter " $b$ " from the Elovich model was lower. Since that the " $b$ " units is $g$ $\mathrm{mg}^{-1}$, this fact shows that the MG adsorption capacity was favored at initial concentrations of 150 and $175 \mathrm{mg} \mathrm{L}^{-1}$. The 
Table 1. Kinetic parameters for the adsorption of MG onto natural kaolin.

\begin{tabular}{|c|c|c|c|c|}
\hline \multirow{2}{*}{ Model } & \multicolumn{4}{|c|}{ Initial MG concentration $\left(\mathrm{mg} \mathrm{L}^{-1}\right)$} \\
\hline & 100 & 125 & 150 & 175 \\
\hline \multicolumn{5}{|l|}{ Pseudo-first order } \\
\hline$q_{1}\left(\mathrm{mg} \mathrm{g}^{-1}\right)$ & 91.51 & 97.95 & 111.6 & 119.95 \\
\hline$k_{1}\left(\min ^{-1}\right)$ & 0.1835 & 0.2397 & 0.0789 & 0.0869 \\
\hline$R^{2}$ & 0.7505 & 0.7336 & 0.7751 & 0.8000 \\
\hline$R_{a d j}^{2}$ & 0.7278 & 0.7094 & 0.7547 & 0.7818 \\
\hline$A R E(\%)$ & 18.60 & 18.26 & 22.75 & 21.35 \\
\hline SSE & 3021.13 & 3681.14 & 4256.23 & 4397.87 \\
\hline$A I C$ & 76.03 & 78.60 & 80.48 & 80.91 \\
\hline \multicolumn{5}{|l|}{ Pseudo-second order } \\
\hline$q_{2}\left(\mathrm{mg} \mathrm{g}^{-1}\right)$ & 97.27 & 103.95 & 118.42 & 127.85 \\
\hline$k_{2} \mathrm{x} 10^{3}\left(\mathrm{~g} \mathrm{mg}^{-1} \mathrm{~min}^{-1}\right)$ & 2.53 & 2.94 & 1.16 & 1.10 \\
\hline$R^{2}$ & 0.8520 & 0.8369 & 0.8673 & 0.8868 \\
\hline$R_{a d j}^{2}$ & 0.8385 & 0.8221 & 0.8552 & 0.8765 \\
\hline$A R E(\%)$ & 14.31 & 14.30 & 16.83 & 15.45 \\
\hline$S S E$ & 1792.25 & 2253.17 & 2509.90 & 2486.60 \\
\hline$A I C$ & 69.24 & 72.21 & 73.62 & 73.49 \\
\hline \multicolumn{5}{|l|}{ Elovich } \\
\hline$b\left(\mathrm{~g} \mathrm{mg}^{-1}\right)$ & 0.0786 & 0.0756 & 0.0563 & 0.0520 \\
\hline$a\left(\mathrm{mg} \mathrm{g}^{-1} \min ^{-1}\right)$ & 175.68 & 250.30 & 75.28 & 80.98 \\
\hline$R^{2}$ & 0.9655 & 0.9654 & 0.9671 & 0.9758 \\
\hline$R_{a d j}^{2}$ & 0.9624 & 0.9623 & 0.9641 & 0.9736 \\
\hline$A R E(\%)$ & 6.59 & 6.47 & 7.71 & 6.91 \\
\hline$S S E$ & 418.16 & 477.95 & 622.82 & 532.38 \\
\hline$A I C$ & 50.32 & 52.05 & 55.50 & 53.46 \\
\hline
\end{tabular}

Elovich model was also suitable to represent other previous studies reporting the adsorption of food dyes onto chitosan ${ }^{65}$.

\subsection{Adsorption isotherms}

The adsorption isotherm of MG dye onto natural kaolin was obtained at $25^{\circ} \mathrm{C}$ and $\mathrm{pH}$ of 6.3 and, it is shown in Figure 9. The isotherm data were fitted using the Freundlich, Langmuir and Sips models, where the results are shown in Table 2. It can be observed in Figure 9 that the isotherm shows a strong initial inclination, followed by a plateau. The initial inclination shows a strong affinity between MG and kaolin and the plateau represents the maximum adsorption capacity. This behavior corresponds to a L2-type isotherm according to the Giles classification ${ }^{66}$.

The statistical parameters presented in Table 2 revealed that the Freundlich and Langmuir models were able to represent the experimental equilibrium data. Despite of Sips model to generate satisfactory statistical parameters, this model overestimated the maximum adsorption capacity and so, it cannot be used to predict the experimental data. The $1 / n_{F}$ value was lower than 1 and consequently, $n_{F}>1$, showing

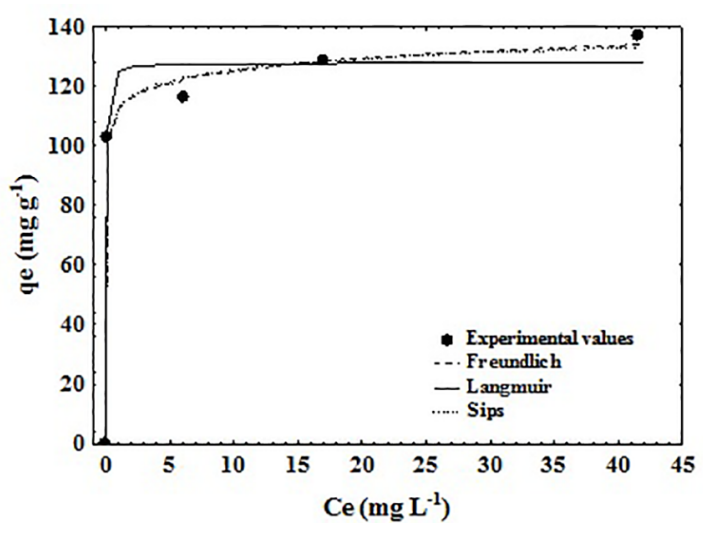

Figure 9. Isotherm curve for the adsorption of $\mathrm{MG}$ onto natural kaolin. Experimental conditions: $\mathrm{pH}=6.3 ; \mathrm{T}=25^{\circ} \mathrm{C}$.

that the MG adsorption onto kaolin was a favorable process. The high $K_{L}$ value confirms the high affinity between the MG dye and kaolin. The $q_{m}$ parameter obtained from the Langmuir model was relatively high and, it was used to determine the quality of the kaolin adsorbent.

In order to verify the efficiency of raw kaolin for the MG dye adsorption, a comparison among the maximum 
Table 2. Equilibrium parameters for the adsorption of MG onto natural kaolin.

\begin{tabular}{|c|c|}
\hline \multicolumn{2}{|c|}{ Equilibrium model } \\
\hline Freundlich & \\
\hline$K_{F}\left(\mathrm{mg} \mathrm{g}^{-1}\right)\left(\mathrm{mg} \mathrm{L}^{-1}\right)^{-1 / n}$ & 112.37 \\
\hline $1 / n_{F}$ & 0.0469 \\
\hline$R^{2}$ & 0.9957 \\
\hline$R_{a d j}^{2}$ & 0.9943 \\
\hline$A R E(\%)$ & 2.03 \\
\hline SSE & 52.77 \\
\hline$A I C$ & 21.78 \\
\hline \multicolumn{2}{|l|}{ Langmuir } \\
\hline$q_{m}\left(\mathrm{mg} \mathrm{g}^{-1}\right)$ & 128 \\
\hline$K_{L}\left(\mathrm{~L} \mathrm{mg}^{-1}\right)$ & 45.33 \\
\hline$R^{2}$ & 0.9829 \\
\hline$R_{a d j}^{2}$ & 0.9772 \\
\hline$A R E(\%)$ & 3.51 \\
\hline SSE & 212.10 \\
\hline$A I C$ & 28.74 \\
\hline \multicolumn{2}{|l|}{ Sips } \\
\hline$q_{S}\left(\mathrm{mg} \mathrm{g}^{-1}\right)$ & 259.42 \\
\hline$K_{S}\left(\mathrm{~L} \mathrm{mg}^{-1}\right)$ & 0.0452 \\
\hline$m_{S}$ & 0.083 \\
\hline$R^{2}$ & 0.9949 \\
\hline$R_{a d j}^{2}$ & 0.9898 \\
\hline$A R E(\%)$ & 2.19 \\
\hline SSE & 63.01 \\
\hline$A I C$ & 42.67 \\
\hline
\end{tabular}

adsorption capacities $\left(q_{m} \mathrm{mg} \mathrm{g}^{-1}\right)$ of several low-cost adsorbents reported in literature was performed, as shown in Table 3. The values in Table 3 were obtained under several different experimental conditions and, therefore, the maximum capacity $\left(q_{m}\right)$ only from the each work was listed herein. Based on the results presented in Table 3 , it can be affirmed that the natural raw kaolin used in this work can be utilized as a promising low-cost adsorbent to remove the MG organic dye from liquid effluents.

\section{Conclusions}

The removal of Malachite Green dye using kaolin clay as adsorbent was systematically investigated under different experimental conditions. The raw kaolin from the Rio Grande do Sul State/Brazil presented interesting characteristics for adsorption purposes. The results indicated that the Elovich model was the more adequate to represent the adsorption kinetic data. The maximum adsorption capacity toward Malachite Green was estimated at around $128 \mathrm{mg} \mathrm{g}^{-1}$, according to the Langmuir model. In summary, the findings from this study demonstrated that the use of raw kaolin as
Table 3. Comparison of Brazilian natural kaolin with other low-cost adsorbents for the adsorption of MG dye.

\begin{tabular}{lc}
\hline Adsorbent & $q_{m}\left(\mathrm{mg} \mathrm{g}^{-1}\right)$ \\
\hline Raw kaolin (This work) & 128 \\
Sphagnum peat moss $^{67}$ & 122 \\
Walnut shell $^{68}$ & 91 \\
Beech sawdust $^{69}$ & 83 \\
Bivalve shell-treated Zea mays L. (maize) $^{70}$ & 82 \\
Maize cob powder $^{71}$ & 81 \\
${\text { Casuarina equisetifolia } \text { needle }^{72}}_{\text {Rattan sawdust }^{73}}$ & 78 \\
Daucus carrot leaves powder $^{74}$ & 63 \\
Persian kaolin $^{75}$ & 53 \\
Lemon peel $^{76}$ & 52 \\
Sea shell powder & \\
Castor bean presscake $^{78}$ & 52 \\
Cerastoderma lamarcki shell $^{79}$ & 42 \\
${\text { Annona squmosa } \text { seed }^{80}}_{\text {Natural zeolite }^{81}}^{\text {Bentonite clay }^{82}}$ & 37 \\
\hline
\end{tabular}

an alternative low-cost adsorbent for the removal Malachite Green from colored effluents is feasible.

\section{Acknowledgments}

The authors are grateful to Federal University of Santa Maria (UFSM), Brazil.

\section{References}

1. Combes RD, Haveland-Smith RB. A review of the genotoxicity of food, drug and cosmetic colours and other azo, triphenylmethane and xanthene dyes. Mutation Research. 1982;98(2):101-243.

2. Ali I, Al-Othman ZA, Alwarthan A. Molecular uptake of congo red dye from water on iron composite nano particles. Journal of Molecular Liquids. 2016;224(Pt A):171-176.

3. Liu S, Wang Q, Ma H, Huang P, Li J, Kikuchi T. Effect of microbubbles on coagulation flotation process of dyeing wastewater. Separation and Purification Technology. 2010;71(3):337-346.

4. Capar G, Yetis U, Yilmaz L. Membrane based strategies for the pre-treatment of acid dye bath wastewaters. Journal of Hazardous Materials. 2006;135(1-3):423-430.

5. Dotto GL, Rodrigues FK, Tanabe EH, Fröhlich R, Bertuol DA, Martins TR, et al. Development of chitosan/bentonite hybrid composite to remove hazardous anionic and cationic dyes from colored effluent. Journal of Environmental Chemical Engineering. 2016;4(3):3230-3239.

6. Georgin J, Dotto GL, Mazutti MA, Foletto EL. Preparation of activated carbon from peanut shell by conventional pyrolysis and microwave irradiation-pyrolysis to remove organic dyes from aqueous solutions. Journal of Environmental Chemical Engineering. 2016;4(1):266-275. 
7. Gupta VK, Ali I, Saini VK, Van Gerven T, Van der Bruggen B, Vandecasteele C. Removal of Dyes from Wastewater Using Bottom Ash. Industrial \& Engineering Chemistry Research. 2005;44(10):3655-3664.

8. Gupta VK, Ali I, Suhas, Mohan D. Equilibrium uptake sorption for the removal of a basic dye (basic red) using low cost adsorbent. Journal of Colloid and Interface Science. 2003;265(2):257-264.

9. Da Cruz Severo E, Anchieta CG, Foletto VS, Kuhn RC, Collazzo GC, Mazutti MA, et al. Degradation of Amaranth azo dye in water by heterogeneous photo-Fenton process using $\mathrm{FeWO}_{4}$ catalyst prepared by microwave irradiation. Water Science and Technology. 2016;73(1):88-94.

10. Anchieta CG, Severo EC, Rigo C, Mazutti MA, Kuhn RC, Muller $\mathrm{EI}$, et al. Rapid and facile preparation of zinc ferrite $\left(\mathrm{ZnFe}_{2} \mathrm{O}_{4}\right)$ oxide by microwave-solvothermal technique and its catalytic activity in heterogeneous photo-Fenton reaction. Materials Chemistry and Physics. 2015;160:141-147.

11. Dotto GL, Meili L, de Souza Abud AK, Tanabe EH, Bertuol DA, Foletto EL. Comparison between Brazilian agro-wastes and activated carbon as adsorbents to remove $\mathrm{Ni}(\mathrm{II})$ from aqueous solutions. Water Science and Technology. 2016;73(11):27132721.

12. Weber CT, Collazzo GC, Mazutti MA, Foletto EL, Dotto GL. Removal of hazardous pharmaceutical dyes by adsorption onto papaya seeds. Water Science and Technology. 2014;70(1):102-107.

13. Ali I, Gupta VK. Advances in water treatment by adsorption technology. Nature Protocols. 2006;1(6):2661-2667.

14. Ali I. The Quest for Active Carbon Adsorbent Substitutes: Inexpensive Adsorbents for Toxic Metal Ions Removal from Wastewater. Separation \& Purification Reviews. 2010;39(3-4):95-171.

15. Ali I. New generation adsorbents for water treatment. Chemical Reviews. 2012;112(10):5073-5091.

16. Ali I, Asim M, Khan TA. Low cost adsorbents for removal of organic pollutants from wastewater. Journal of Environmental Management. 2012;113:170-183.

17. Ali I. Water Treatment by Adsorption Columns: Evaluation at Ground Level. Separation \& Purification Reviews. 2014;43(3):175-205.

18. Demirbas A. Agricultural based activated carbons for the removal of dyes from aqueous solutions: A review. Journal of Hazardous Materials. 2009;167(1-3):1-9.

19. Foletto EL, Weber CT, Bertuol DA, Mazutti MA. Application of Papaya Seeds as a Macro-/Mesoporous Biosorbent for the Removal of Large Pollutant Molecule from Aqueous Solution: Equilibrium, Kinetic, and Mechanism Studies. Separation Science and Technology. 2013;48(18):2817-2824.

20. Brito SMO, Andrade HMC, Soares LF, Azevedo RP. Brazil nut shells as a new biosorbent to remove methylene blue and indigo carmine from aqueous solutions. Journal of Hazardous Materials. 2010;174(1-3):84-92.

21. Postai DL, Demarchi CA, Zanatta F, Melo DCC, Rodrigues CA. Adsorption of rhodamine $\mathrm{B}$ and methylene blue dyes using waste of seeds of Aleurites Moluccana, a low cost adsorbent. Alexandria Engineering Journal. 2016;55(2):1713-1723.
22. Paz DS, Baiotto A, Schwaab M, Mazutti MA, Bassaco MM, Bertuol DA, et al. Use of papaya seeds as a biosorbent of methylene blue from aqueous solution. Water Science and Technology. 2013;68(2):441-447.

23. Zimmermann BM, Dotto GL, Mazutti MA, Kuhn RC, Treichel $\mathrm{H}$, Foletto EL. Adsorption of hazardous dye Rhodamine B onto Brazilian natural bentonite. International Journal of Environmental Technology and Management. 2016;19(1):1-15.

24. Liu P, Zhang L. Adsorption of dyes from aqueous solutions or suspensions with clay nano-adsorbents. Separation and Purification Technology. 2007;58(1):32-39.

25. Murray HH. Applied Clay Mineralogy, Volume 2. Occurrences, Processing and Applications of Kaolins, Bentonites, Palygorskitesepiolite, and Common Clays. $1^{\text {st }}$ Ed. Amsterdam: Elsevier Science; 2006.

26. Peralta-Sánchez MG, Morales-Carrera AM, Varajão AFDC, Ferreira MM. Availability of the kaolin from Quadrilátero Ferrífero for the ceramic industry. Cerâmica. 2011;57(343):254-262.

27. Menezes RA, Paz SPA, Angélica RS, Neves RF, Pergher SBC. Color and shade parameters of ultramarine zeolitic pigments synthesized from kaolin waste. Materials Research. 2014;17(Suppl. 1):23-27.

28. Barata MS, Angélica RS. Characterization of kaolin wastes from kaolin mining industry from the amazon region as raw material for pozzolan production. Cerâmica. 2012;58(345):36-42.

29. Varela ML, Formiga FL, Dutra RPS, Nascimento RM, Paskocimas CA. Influence of kaolin waste addition on technological properties of a standard stoneware formulation produced in industrial scale. Cerâmica. 2009;55(334):209-215.

30. Oliveira SP, Silva WLL, Viana RR. Evaluation of the capacity of adsorption of methylene blue die in aqueous solutions in natural kaolinite and intercalated with potassium acetate. Cerâmica. 2013;59(350):338-344.

31. Tavares LC, Lemos VP, Pinheiro MHT, Filho HAD, Fernandes KG. Adsorption of nitrate on kaolinite from kaolin waste modified with urea. Cerâmica. 2013;59(352):640-648.

32. Rocha Junior CAF, Angélica RS, Neves RF. Sinthesis of faujasite-type zeolite: comparison between processed and flint kaolin. Cerâmica. 2015;61(358):259-268.

33. Silva Filho SH, Bieseki L, Silva AR, Maia AAB, San Gil RAS, Pergher SBC. Synthesis of Zeolite A employing Amazon kaolin waste. Cerâmica. 2015;61(360):409-413.

34. Gerotto MV, Cabo SS, Innocentini MDM, Pandolfelli VC. Kaolin and meta-kaolin application as a microsilica alternative for high-alumina self-flowing refractory castables. Cerâmica. 2000;46(300):200-209.

35. Souza ETA, Monteiro SN, Vieira CMF. Ceramic tile with granite and kaolinitic clay. Cerâmica. 2004;50(314):122-127.

36. Vieira CMF, Peçanha Jr LA, Monteiro SN. Effect of kaolinitic clays from the State of Rio de Janeiro in the composition of whiteware floor tile bodies. Cerâmica. 2006;52(322):138-145.

37. Guerra DL, Sousa JA, Airoldi C, Viana RR. Evaluation of intercaled kaolinite efficiency with dimetilsulfoxide in adsorption with $\mathrm{Zn}(\mathrm{II})$ in aqueous medium - kinetics of the adsorption process. Cerâmica. 2008;54(331):273-279. 
38. Maia AAB, Saldanha E, Angélica RS, Souza CAG, Neves RF. The use of kaolin wastes from the Amazon region on the synthesis of zeolite A. Cerâmica. 2007;53(327):319-324.

39. Reyes CAR, Williams C, Alarcón OMC. Nucleation and growth process of sodalite and cancrinite from kaolinite-rich clay under low-temperature hydrothermal conditions. Materials Research. 2013;16(2):424-438.

40. Melo CR, Riella HG. Synthesis of NaA zeolites from kaolin for obtaining $5 \mathrm{~A}$ zeolites through ion exchange. Cerâmica. 2010;56(340):340-346.

41. Rahman A, Urabe T, Kishimoto N. Color removal of reactive procion dyes by clay adsorbents. Procedia Environmental Sciences. 2013;17:270-278.

42. Vimonses V, Lei S, Jin B, Chow CWK, Saint C. Adsorption of congo red by three Australian kaolins. Applied Clay Science. 2009;43(3-4):465-472.

43. Benguella B, Yacouta-Nour A. Elimination des colorants acides en solution aqueuse par la bentonite et le kaolin. Comptes Rendus Chimie. 2009;12(6-7):762-771.

44. Nandi BK, Goswami A, Purkait MK. Removal of cationic dyes from aqueous solutions by kaolin: Kinetic and equilibrium studies. Applied Clay Science. 2009;42(3-4):583-590.

45. Lagergren S. About the theory of so-called adsorption of soluble substances. Kungliga Svenska Vetenskapsakademiens. 1898;24(4):1-39.

46. Ho YS, Mckay G. Kinetic Models for the Sorption of Dye from Aqueous Solution by Wood. Process Safety and Environmental Protection. 1998;76(2):183-191.

47. Zeldowitsch J. Über Den mechanismus Der katalytischen oxydation Von CO an $\mathrm{MnO}_{2}$. Acta Physicochemical. 1934;1:449-464.

48. Freundlich H. Über die adsorption in Lösungen. Leipzig: W. Engelmann; 1906. 98 p.

49. Langmuir I. The adsorption of gases on plane surfaces of glass, mica and platinum. Journal of the American Chemical Society. 1918;40(9):1361-1403.

50. Sips R. On the Structure of a Catalyst Surface. Journal of Chemical Physics. 1948;16(5):490-495.

51. El-Khaiary MI, Malash GF. Common data analysis errors in batch adsorption studies. Hydrometallurgy. 2011;105(3-4):314-320.

52. Bozdogan H. Model selection and Akaike's information criterion (AIC): The general theory and its analytical extensions. Psychometrika. 1987;52(3):345-370.

53. Dotto GL, Costa JAV, Pinto LAA. Kinetic studies on the biosorption of phenol by nanoparticles from Spirulina sp. LEB 18. Journal of Environmental Chemical Engineering. 2013;1(4):1137-1143.

54. Nandi BK, Goswami A, Purkait MK. Adsorption characteristics of brilliant green dye on kaolin. Journal of Hazardous Materials. 2009;161(1):387-395.

55. Zhu HY, Jiang R, Xiao L. Adsorption of an anionic azo dye by chitosan $/ \mathrm{kaolin} / \gamma-\mathrm{Fe}_{2} \mathrm{O}_{3}$ composites. Applied Clay Science. 2010;48(3):522-526.

56. Nallis K, Katsumata K, Isobe T, Okada K, Bone P, Othman R. Preparation and UV-shielding property of $\mathrm{Zr}_{0.7} \mathrm{Ce}_{0.3} \mathrm{O}_{2}$-kaolinite nanocomposites. Applied Clay Science. 2013;80-81:147-153.
57. Volzone C, Ortiga J. Removal of gases by thermal-acid leached kaolinitic clays: Influence of mineralogical composition. Applied Clay Science. 2006;32(1-2):87-93.

58. Bikiaris D, Daniilia S, Sotiropoulou S, Katsimbiri O, Pavlidou E, Moutsatsou AP, Chryssoulakis Y. Ochre-differentiation through micro-Raman and micro-FTIR spectroscopies: application on wall paintings at Meteora and Mount Athos, Greece. Spectrochimica Acta Part A: Molecular and Biomolecular Spectroscopy. 2000;56(1):3-18.

59. Foletto EL, Volzone C, Morgado AF, Porto LM. Obtenção e Caracterização de Materiais Argilosos Quimicamente Ativados para Utilização no Descoramento de Óleo Vegetal. Materials Research. 2001;4(3):211-215.

60. Foletto EL, Volzone C, Porto LM. Performance of an Argentinian acid-activated bentonite in the bleaching of soybean oil. Brazilian Journal of Chemical Engineering. 2003;20(2):139-145.

61. Hildebrando EA, Andrade CGB, Rocha Junior CAF, Angélica RS Valenzuela-Diaz FR, Neves RF. Synthesis and characterization of zeolite $\mathrm{NaP}$ using kaolin waste as a source of silicon and aluminum. Materials Research. 2014;17(Suppl. 1):174-179.

62. Sperinck S, Raiteri P, Marks N, Wright K. Dehydroxylation of kaolinite to metakaolin - a molecular dynamics study. Journal of Materials Chemistry. 2011;21:2118-2125.

63. Rodrigues M, Souza AG, Santos IMG. Brazilian Kaolin Wastes: Synthesis of Zeolite P at Low-Temperature. American Chemical Science Journal. 2016;12(4):1-11.

64. Severo E, Abaide ER, Anchieta CG, Foletto VS, Weber CT, Garlet TB, et al. Preparation of zinc tungstate $\left(\mathrm{ZnWO}_{4}\right)$ particles by solvo-hydrothermal technique and their application as support for inulinase immobilization. Materials Research. 2016;19(4):781-785.

65. Dotto GL, Pinto LAA. Adsorption of food dyes acid blue 9 and food yellow 3 onto chitosan: Stirring rate effect in kinetics and mechanism. Journal of Hazardous Materials. 2011;187(1-3):164-170.

66. Giles CH, MacEwan TH, Nakhwa SN, Smith D. Studies in adsorption. Part XI. A system of classification of solution adsorption isotherms, and its use in diagnosis of adsorption mechanisms and in measurement of specific surface areas of solids. Journal of Chemical Society. 1960;3973-3993.

67. Hemmati F, Norouzbeigi R, Sarbisheh F, Shayesteh H. Malachite green removal using modified sphagnum peat moss as a lowcost biosorbent: Kinetic, equilibrium and thermodynamic studies. Journal of the Taiwan Institute of Chemical Engineers. 2016;58:482-489.

68. Dahri MK, Kooh MRR, Lim LBL. Water remediation using low cost adsorbent walnut shell for removal of malachite green: Equilibrium, kinetics, thermodynamic and regeneration studies. Journal of Environmental Chemical Engineering. 2014;2(3):1434-1444.

69. Witek-Krowiak A. Analysis of influence of process conditions on kinetics of malachite green biosorption onto beech sawdust. Chemical Engineering Journal. 2011;171(3):976-985. 
70. Jalil AA, Triwahyono S, Yaakob MR, Azmi ZZ, Sapawe N, Kamarudin NH, et al. Utilization of bivalve shell-treated Zea mays L. (maize) husk leaf as a low-cost biosorbent for enhanced adsorption of malachite green. Bioresource Technology. 2012;120:218-224.

71. Sonawane GH, Shrivastava VS. Kinetics of decolourization of malachite green from aqueous medium by maize cob (Zea maize): An agricultural solid waste. Desalination. 2009;247(1-3):430-441.

72. Dahri MK, Kooh MRR, Lim LBL. Application of Casuarina equisetifolia needle for the removal of methylene blue and malachite green dyes from aqueous solution. Alexandria Engineering Journal. 2015;54(4):1253-1263.

73. Hameed BH, El-Khaiary MI. Malachite green adsorption by rattan sawdust: Isotherm, kinetic and mechanism modeling. Journal of Hazardous Materials. 2008;159(2-3):574-579.

74. Kushwaha AK, Gupta N, Chattopadhyaya MC. Removal of cationic methylene blue and malachite green dyes from aqueous solution by waste materials of Daucus carota. Journal of Saudi Chemical Society. 2014;18(3):200-207.

75. Tehrani-Bagha AR, Nikkar H, Mahmoodi NM, Markazi M, Menger FM. The sorption of cationic dyes onto kaolin: Kinetic, isotherm and thermodynamic studies. Desalination. 2011;266(1-3):274-280.

76. Kumar KV. Optimum sorption isotherm by linear and nonlinear methods for malachite green onto lemon peel. Dyes and Pigments. 2007;74(3):595-597.
77. Chowdhury S, Saha P. Sea shell powder as a new adsorbent to remove Basic Green 4 (Malachite Green) from aqueous solutions: Equilibrium, kinetic and thermodynamic studies. Chemical Engineering Journal. 2010;164(1):168-177.

78. Magriotis ZM, Carvalho MZ, Sales PF, Alves FC, Resende RF, Saczk AA. Castor bean (Ricinus communis L.) presscake from biodiesel production: An efficient low cost adsorbent for removal of textile dyes. Journal of Environmental Chemical Engineering. 2014;2(3):1731-1740.

79. Kazemi SY, Biparva P, Ashtiani E. Cerastoderma lamarcki shell as a natural, low cost and new adsorbent to removal of dye pollutant from aqueous solutions: Equilibrium and kinetic studies. Ecological Engineering. 2016;88:82-89.

80. Santhi T, Manonmani S, Vasantha VS, Chang YT. A new alternative adsorbent for the removal of cationic dyes from aqueous solution. Arabian Journal of Chemistry. 2016;9(Supp1 1):S466-S474.

81. Wang S, Ariyanto E. Competitive adsorption of malachite green and $\mathrm{Pb}$ ions on natural zeolite. Journal of Colloid and Interface Science. 2007;314(1):25-31.

82. Tahir SS, Rauf N. Removal of a cationic dye from aqueous solutions by adsorption onto bentonite clay. Chemosphere. 2006;63(11):1842-1848. 